\title{
Quantification of B cells and T lymphocyte subsets in bovine leukemia virus infected dairy cows
}

\author{
Quantificação da população de linfócitos B e das \\ subpopulações de linfócitos $\mathbf{T}$ em bovinos infectados pelo \\ vírus da leucose enzoótica bovina
}

\author{
Alice Maria Melville Paiva Della Libera'; Maiara Garcia Blagitz²; \\ Camila Freitas Batista ${ }^{3}$; Andreia Oliveira Latorre ${ }^{4}$; \\ Claúdia Regina Stricagnolo 5 ; Fernando Nogueira de Souza ${ }^{6 *}$
}

\begin{abstract}
The aim of the present trial was to determine the frequencies and absolute number of $\mathrm{B}$ and $\mathrm{T}$ lymphocytes subpopulations in bovine leukemia virus (BLV)-infected dairy cows with distinct lymphocyte profile known as non-leukemic (AL) and persistent lymphocytosis (PL). Thus, 15 animals were selected and divided uniformly in three groups (negative, AL, PL). The BLV infection was detected by agar gel immunodiffusion and enzyme-linked immunosorbent-assay. The lymphocytes subsets were evaluated using monoclonal antibodies by flow cytometry. The results of the present study pointed out to an increase in B lymphocytes, and also an augment in $\mathrm{CD}^{+}$and $\mathrm{CD} 11 \mathrm{~b}^{+}$cells in animals showing PL. Consequently, it can be observed a decrease in the percentage of $\mathrm{T}$ cells subsets in these animals. Conversely, no significant alterations in the absolute number of the $\mathrm{T}$ lymphocytes, $\mathrm{T} \mathrm{CD} 4^{+}$cells and $\mathrm{T}$ $\mathrm{CD}^{+}$lymphocytes were found in BLV-infected dairy cows with PL. Therefore, the correlation between the absolute numbers of B- and T cell subsets in the peripheral blood applied to each group showed a significant and positive strong correlation between numbers of B cells and T cells or T CD8 ${ }^{+}$cells in the PL animals, although the same cannot be predicted for $\mathrm{T} \mathrm{CD} 4^{+}$lymphocytes. No such correlation was encountered for the AL and negative-control animals.
\end{abstract}

Key words: Enzootic leukosis, persistent lymphocytosis, B lymphocytes, $\mathrm{T}$ lymphocytes

\section{Resumo}

O objetivo do presente trabalho foi avaliar a frequência e número absoluto de linfócitos $\mathrm{B}$ e das subpopulações de linfócitos T em bovinos infectados pelo vírus da leucemia bovina (BLV) com distintos

\footnotetext{
${ }^{1}$ Médica Veterinária, Prof ${ }^{\mathrm{a}} \mathrm{Dr}^{\mathrm{a}}$, Dept ${ }^{\mathrm{o}}$ de Clínica Médica, Faculdade de Medicina Veterinária e Zootecnia, Universidade de São Paulo, USP, São Paulo, SP. E-mail: dellalibera@usp.br

${ }^{2}$ Médica Veterinária, Prof ${ }^{\mathrm{a}}$ Dr $^{\mathrm{a}}$, Faculdade de Medicina Veterinária, Universidade Federal do Paraná, UFPR, Campus Palotina. Palotina, PR. E-mail: magblagitz@usp.br

${ }^{3}$ Médica Veterinária, Doutoranda em Ciências, Dept ${ }^{\circ}$ de Clínica Médica, Faculdade de Medicina Veterinária e Zootecnia, USP, São Paulo, SP. E-mail: camila_vet69@yahoo.com.br

${ }^{4}$ Médica Veterinária, Pós-Doutoranda, Dept ${ }^{\circ}$ de Patologia Faculdade de Medicina Veterinária e Zootecnia, USP, São Paulo, SP. E-mail: alatorre@usp.br

${ }_{5}^{5}$ Biomédica, Dept ${ }^{\circ}$ de Clínica Médica, Faculdade de Medicina Veterinária e Zootecnia, USP, São Paulo, SP. E-mail: lab_imuno@, hotmal.com

${ }^{6}$ Médico Veterinário, Mestre em Ciências, Dept ${ }^{\circ}$ de Clínica Médica, Faculdade de Medicina Veterinária e Zootecnia, USP, São Paulo, SP. E-mail: nogueirasouza@yahoo.com.br

* Author for corespondence
} 
perfis leucocitários conhecidos como não leucêmicos (AL) e com linfocitose persistente (LP). Deste modo, 15 animais foram selecionados e divididos uniformemente em três grupos (negativo, AL e LP). A infecção pelo vírus da BLV foi detectada por imunodifusão em ágar gel e por ensaio imunoenzimático. A quantificação das populações de linfócitos B e T foi determinada por citometria de fluxo utilizando anticorpos monoclonais. Os resultados do presente estudo apontaram para aumento da população de linfócitos $\mathrm{B}$, e também das células $\mathrm{CD}^{+}$e $\mathrm{CD} 11 \mathrm{~b}^{+}$, que geralmente são alvo da infecção pelo vírus da BLV, nos animais com LP. Consequentemente pode-se observar redução da porcentagem de linfócitos $\mathrm{T}, \mathrm{T} \mathrm{CD} 4^{+}$no sangue periférico, e de linfócitos $\mathrm{T}, \mathrm{T} \mathrm{CD} 4^{+}$e $\mathrm{T} \mathrm{CD} 8^{+}$nas células mononucleares do sangue periférico isoladas por gradiente de centrifugação. No entanto, nenhuma alteração no número absoluto de linfócitos T, T CD4 ${ }^{+}$e T CD8 ${ }^{+}$no sangue periférico foi encontrada nos animais manifestando LP. Entretanto, encontrou-se correlação alta e significativa entre o número absoluto de linfócitos $\mathrm{T}$ e $\mathrm{T} \mathrm{CD}^{+}$e o número absoluto de linfócitos $\mathrm{B}$ no sangue periférico nos animais manifestando LP, não encontrando a mesma correlação com os linfócitos T CD4 ${ }^{+}$. Além disso, não foram observadas correlações significativas entre o número absoluto de linfócitos T, T CD4 $4^{+}$e T CD $8^{+}$e o número absoluto de linfócitos B no sangue periférico nos animais AL e negativos.

Palavras-chave: Leucose enzoótica bovina, linfocitose persistente, linfócitos B, linfócitos T

\section{Introduction}

Bovine leukemia virus (BLV) is the etiologic agent of bovine leukosis caused by a $\delta$-retrovirus, which is the most common neoplastic disease of cattle. Although, it is successfully eradicated in some regions of Europe, BLV is among the most widespread livestock pathogens in many countries, especially in dairy herds (GILLET et al., 2007).

Infection with BLV in cattle may remain clinically silent or may emerge as a persistent lymphocytosis (PL), and more rarely develop a B-cell lymphoma. $\mathrm{PL}$ is characterized as a chronic elevation in the number of B circulating lymphocytes and it is found in approximately 20-30\% of BLV-infected cattle. These infected cells often co-express the CD5 molecule. Another marker, the CD11b integrin molecule better defines the leukemic cell populations (GILLET et al., 2007). However, regarding the $\mathrm{T}$ cell subpopulations no consensus was found. There are some studies that showed reduction in the $\mathrm{T}$ lymphocyte subsets in BLV-infected cattle with PL (GATEI et al., 1989) or with lymphoma (WU et al., 1999). Conversely, other studies reported an increase (WILLIAMS; AMBRORSKI; DAVIS, 1988) or no alteration (TAYLOR et al., 1992) in T lymphocytes in BLV-infected cattle.

It should be emphasized that all these studies use only the agar gel immunodiffusion test (AGID) to identified BLV infected animals. In spite of the high sensitivity of this test, it is known that this assay showed a low specificity compared to enzyme-linked immunosorbent-assay test (ELISA) (NGUYEN; MAES, 1993).

Thus, in order to shed light on these differences observed in lymphocyte subsets in the blood of BLV-infected cattle the aim of the present study was to determine the percentage of these cells in the blood of BLV-infected dairy cows with distinct lymphocyte profile known as non-leukemic (AL) and with PL.

\section{Materials and Methods}

In the present study, fifteen clinically healthy Holstein cows in the middle of lactation were selected from a dairy farm with approximately 100 lactating cows, and divided uniformly according to the sera test and the hematological profile in three groups: negative in both tests (AGID and ELISA) without any hematological alterations (DIVERS; PIKERS, 2008); positive in both tests and without any hematological alterations (DIVERS; PIKERS, 2008) known as AL; and positive in both tests with PL. The sera of animals were evaluated by AGID $\left(\right.$ Tecpar $^{\circledR}$, Curitiba, Brazil) and ELISA (VMRD Pullman Inc. Corp ${ }^{\circledR}$, Pullman, USA, cat. number 284-5) using the glycoprotein gp51. BLV-infected 
cattle were classified as PL when the lymphocyte counts exceed $10,000 / \mathrm{mL}$ and the leukocytes counts exceed $15,000 / \mathrm{mL}$ as established by Thurmond et al. (1990), Brenner, Avidar and Lahav (2007). All cows employed in the present study were sampled twice at 72-days interval to confirm BLV infection and differentiate PL from AL animals.

The total number of leukocytes per microliter of the peripheral blood was measured using an automatic cell count (ABX VET ABC, Horiba ABX Diagnostic $^{\circledR}$, Montpellier, France). The differential leukocyte count was performed by routine blood smears and each leukocyte numbers per microliter was estimated by multiplying the percentage of each leukocyte by the total leukocyte count.

The peripheral blood mononuclear cells (PBMC) were isolated on a Ficoll-Paque ${ }^{\mathrm{TM}}$ Plus $^{\circledR}$ (GE Healthcare, Pascataway, USA, cat. number 17-144003) density $1,077 \mathrm{~g} / \mathrm{cm}^{3}$ gradient of centrifugation. Afterwards, the leukocytes concentration was determined by counting in Neubauer camber and their concentration was adjusted to $2 \times 10^{6}$ cells $/ \mathrm{mL}$.

The source of monoclonal antibodies (mAbs) against bovine lymphocytes was as follows: mouse IgG1 anti-bovine CD3 (T lymphocytes, MM1A), mouse IgG2a anti-bovine CD4 (T CD4 ${ }^{+}$ lymphocytes, IL-A11), mouse $\operatorname{IgM}$ anti-bovine CD8 $\alpha$ ( $\mathrm{T} \mathrm{CD}^{+}$lymphocytes, BAQ111A), mouse IgG2a anti-bovine CD5 (B29A) and mouse IgG1 anti-bovine CD11b (MM12A) (VMRD, Pullman, USA). The secondary antibodies used in the present study was goat anti-mouse IgG1 conjugated with phycoerythrin-Cy5 (PE-Cy5) (M32018), goat anti-mouse IgM conjugated with fluorescein isothiocyanate (FITC) (M31501) and goat antimouse IgG2a conjugated with phycoerythrin (PE) (M32204) (Invitrogen, Carlsbad, CA, USA). The
$\mathrm{B}$ cells were identified using the mouse anti-bovine CD21 conjugated with PE (MCA1424PE) (AbD Serotec, Oxford, England).

Fresh venous blood was collected in tubes containing heparin as anticoagulant. For each cow, $300 \mu \mathrm{L}$ of whole blood and $200 \mu \mathrm{L}$ of PBMC were used. Firstly, the erythrocytes from the whole blood were submitted to hypotonic lyses followed by washed steps with phosphate buffer saline (PBS) $\mathrm{pH}$ 7.2. Thereafter, for immunofluorescence staining, the leukocytes from the whole blood and the PBMC were incubated with the $\mathrm{mAbs}$ for $30 \mathrm{~min}$ at room temperature. Then, after washed steps, the cells were incubated for $30 \mathrm{~min}$ with the secondary antibody at room temperature in the dark. After washed steps, the cells were centrifuged for $8 \mathrm{~min}$ at $250 \mathrm{~g}$ and were suspended in PBS containing $0.1 \%$ of bovine serum albumin. The samples were analyzed by flow cytometry (FACSCalibur ${ }^{\mathrm{TM}}$, Becton Dickinson Immunocytometry System ${ }^{\mathrm{TM}}$, San Diego, CA, USA) where 20,000 gated cells (B, CD5 ${ }^{+}$or T cells) were acquired (Figure 1). Then, the data were read using the Flow Jo Tree Star software (TreeStar Inc., Ashland, OR, USA).

Gaussian distribution was confirmed with the Kolmogorov and Smirnov test. A repeated measures ANOVA was then used to look for significant differences among group means (negative, AL and PL). If a significant difference was identified, it was followed by Tukey-Kramer multiple means comparison test. Correlation between the absolute numbers of B- and T-lymphocytes subpopulations for each of the three groups was estimated by Pearson correlation test. Statistical analysis was performed using GraphPad Prisma 5.0 software (GraphPad Software, Inc., San Diego, CA, USA). Results are reported as means $\pm \mathrm{SD}$. A value of $\mathrm{P} \leq$ 0.05 was considered significant. 
Figure 1. A. Dot plots showing the cell granularity (side scatter [SSC]) and intensity of fluorescence in the red channel (FL3-H) distributed in logarithm scale $\left(10^{0}\right.$ a $\left.10^{4}\right)$. The gated cells represent the $\mathrm{T}$ cells $\left(\mathrm{CD}^{+}\right)$from the whole blood based on fluorescence intensity after used monoclonal antibodies. B. Afterwards, the percentage of T $\mathrm{CD}^{+}$and $\mathrm{T}$ $\mathrm{CD}^{+}$cells were analyzed. The upper quadrant in the left demonstrates the $\mathrm{T} \mathrm{CD}^{+}$cells $\left(\mathrm{FL}^{+} / \mathrm{FL}^{-}\right)$. The lower quadrant in the right demonstrates the $\mathrm{T} \mathrm{CD}^{+}$cells $\left(\mathrm{FL} 1 / \mathrm{FL} 2^{+}\right)$. The upper quadrant in the right shows the $\mathrm{T} \mathrm{CD}^{+} /$ $\mathrm{CD}^{+}$cells $\left(\mathrm{FL}^{+} / \mathrm{FL}^{+}\right)$. The lower quadrant in the left represents the T CD4/CD8 cells (FL1 $/ \mathrm{FL}^{-}$).

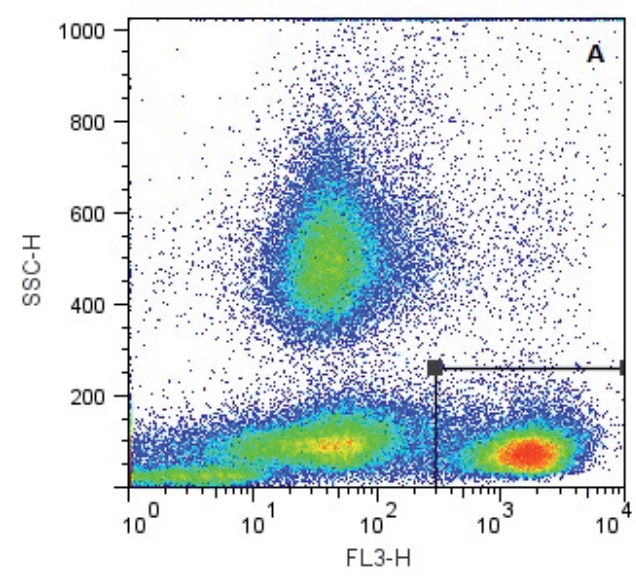

Source: Elaborations of the authors.

\section{Results}

The hematological profile from the fifteen animals and divided in the three groups was showed in tables 1 and 2. As expected, higher leukocytes count due to the augment in the absolute number of lymphocytes was observed in BLV-infected cows with PL.

The measurement of the lymphocyte subsets by flow cytometry in the circulating peripheral blood and even in the PBMC isolated by a gradient of

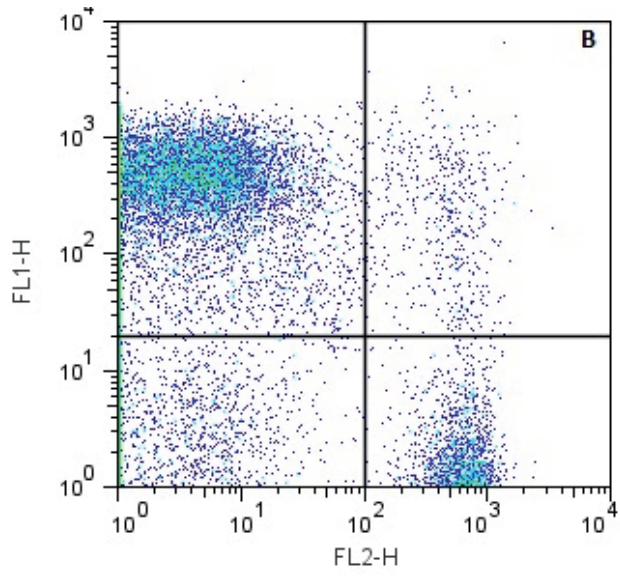

centrifugation showed an increase in B lymphocytes $\left(\mathrm{CD} 21^{+}\right)$and also an augment in $\mathrm{CD}^{+}$and $\mathrm{CD} 11 \mathrm{~b}^{+}$ cells in BLV-infected dairy cows with PL (Tables 3 and 4). As a result of the significant augment of B cells, a corresponding decrease in the percentage of others cells types as $\mathrm{T}$ cells were found (Tables 3 and 4). Nevertheless, the absolute numbers of the T cells subsets were not altered in the present study (Table 3).

Table 1. Median (minimum - maximum) absolute values $\left(10^{3} / \mu \mathrm{L}\right)$ of leukocytes, neutrophils, lymphocytes, eosinophils and monocytes in the peripheral blood of BLV-free $\left(\mathrm{BLV}^{-}\right)$and BLV-infected cattle $\left(\mathrm{BLV}^{+}\right)$without $(\mathrm{AL})$ and with persistent lymphocytosis $\left(\mathrm{PL}^{+}\right)$.

\begin{tabular}{|c|c|c|c|c|c|}
\hline & $\begin{array}{c}\text { Leukocytes } \\
\left(10^{3} / \mu \mathrm{L}\right)\end{array}$ & $\begin{array}{c}\text { Neutrophils } \\
\left(10^{3} / \mu \mathrm{L}\right)\end{array}$ & $\begin{array}{l}\text { Lymphocytes } \\
\left(10^{3} / \mu \mathrm{L}\right)\end{array}$ & $\begin{array}{c}\text { Eosinophils } \\
\left(10^{3} / \mu \mathrm{L}\right)\end{array}$ & $\begin{array}{c}\text { Monocytes } \\
\left(10^{3} / \mu \mathrm{L}\right)\end{array}$ \\
\hline $\mathbf{B L V}^{+} / \mathbf{P L}^{+}$ & $19,7(17,5-35,7)^{\mathrm{a}}$ & $4,37(3,09-5,71)$ & $14,38(11,70-29,27)^{a}$ & $0,79(0,36-1,40)$ & $0,27(0,18-0,71)$ \\
\hline CV (\%) & 31.75 & 21.42 & 39.04 & 50.59 & 62.86 \\
\hline $\mathbf{B L V}+/ \mathbf{A L}$ & $10,80(9,6-12,0)^{\mathrm{b}}$ & $2,94(2,30-4,10)$ & $6,50(5,78-7,24)^{b}$ & $0,76(0,70-0,96)$ & $0,29(0,11-0,46)$ \\
\hline CV (\%) & 9.16 & 24.69 & 8.39 & 14.10 & 46.43 \\
\hline BLV- & $10,8(9,6-11,7)^{\mathrm{b}}$ & $2,21(1,69-4,68)$ & $6,60(5,70-8,53)^{b}$ & $0,96(0,11-1,48)$ & $0,23(0,10-0,61)$ \\
\hline CV (\%) & 9.21 & 46.21 & 17.89 & 63.04 & 84.00 \\
\hline
\end{tabular}

Different letters between lines indicated $\mathrm{P} \leq 0.05$. CV: coefficient of variation

Source: Elaborations of the authors. 
Table 2. Median (minimum - maximum) percentages (\%) of leukocytes, neutrophils, lymphocytes, eosinophils and monocytes in the peripheral blood of BLV-free (BLV) and BLV-infected cattle $\left(\mathrm{BLV}^{+}\right)$without (AL) and with persistent lymphocytosis $\left(\mathrm{PL}^{+}\right)$performed by routine blood smears.

\begin{tabular}{lcccc}
\hline & $\begin{array}{c}\text { Neutrophils } \\
\left(\mathbf{1 0}^{\mathbf{3}} / \boldsymbol{\mu L} \mathbf{L}\right)\end{array}$ & Lymphocytes $\left(\mathbf{1 0}^{\mathbf{3} / \boldsymbol{\mu L})}\right.$ & Eosinophils $\left(\mathbf{1 0}^{\mathbf{3}} / \boldsymbol{\mu L} \mathbf{L}\right)$ & $\begin{array}{c}\text { Monocytes } \\
(\mathbf{1 0} / \boldsymbol{\mu} \mathbf{L})\end{array}$ \\
\hline $\mathbf{B L V}^{+} / \mathbf{P L}^{+}$ & $16(16-25)^{*}$ & $77(66-82)^{\mathrm{a}}$ & $04(01-08)$ & $01(01-02)$ \\
$\mathbf{C V}(\mathbf{\%})$ & 21.70 & 8.61 & 68.09 & 39.29 \\
$\mathbf{B L V} / \mathbf{A L}$ & $30(24-35)$ & $59(56-67)^{\mathrm{b}}$ & $07(06-10)$ & $03(01-04)$ \\
$\mathbf{C V}(\mathbf{\%})$ & 16.99 & 8.16 & 22.57 & 74.54 \\
$\mathbf{B L V}$ & $23(14-39)$ & $66(50-78)^{\mathrm{ab}}$ & $10(01-13)$ & $02(01-05)$ \\
$\mathbf{C V}(\%)$ & 41.86 & 18.06 & 61.83 & 43.85 \\
\hline
\end{tabular}

Different letters between lines indicated $\mathrm{P} \leq 0.05 .{ }^{*} \mathrm{P}=0.06$. CV: coefficient of variation

Source: Elaborations of the authors.

Table 3. Percentage (\%) and absolute values $\left(10^{3} / \mu \mathrm{L}\right)$ of lymphocyte subsets in the peripheral blood of BLV-free (BLV) and $\mathrm{BLV}$-infected cattle $\left(\mathrm{BLV}^{+}\right)$without $(\mathrm{AL})$ and with persistent lymphocytosis $\left(\mathrm{PL}^{+}\right)$performed by flow cytometry.

\begin{tabular}{|c|c|c|c|}
\hline Lymphocytes & BLV $^{-}$ & $\mathbf{B L V}^{+} / \mathbf{A L}$ & $\mathbf{B L V}^{+} / \mathbf{P L}^{+}$ \\
\hline $\mathrm{CD21}^{+}(\%)$ & $20.82 \pm 3.65^{\mathrm{a}^{*}}$ & $23.40 \pm 8.25^{\mathrm{a}}$ & $41.82 \pm 6.30^{b}$ \\
\hline $\mathrm{CD3}^{+}(\%)$ & $26.35 \pm 4.21^{\mathrm{a}^{*}}$ & $24.69 \pm 4.78^{\mathrm{a}}$ & $15.27 \pm 3.53^{b}$ \\
\hline $\mathrm{CD3}^{+} \mathrm{CD4}^{+}(\%)$ & $8.50 \pm 2.29^{\mathrm{a}}$ & $8.48 \pm 2.65^{\mathrm{a}}$ & $3.95 \pm 1.36^{\mathrm{b}}$ \\
\hline $\mathrm{CD3}^{+} \mathrm{CD8}^{+}(\%)$ & $9.04 \pm 3.80$ & $11.10 \pm 3.70$ & $6.47 \pm 2.26$ \\
\hline $\mathrm{CD4}^{+} / \mathrm{CD8}^{+}$ & $1.07 \pm 0.43$ & $0.86 \pm 0.31$ & $0.70 \pm 0.40$ \\
\hline $\mathrm{CD5}^{+} \mathrm{CD} 11 \mathrm{~b}^{+}(\%)$ & $22.50 \pm 9.57^{\mathrm{a}}$ & $26.01 \pm 6.15^{\mathrm{ab}}$ & $37.56 \pm 9.88^{b}$ \\
\hline $\mathrm{CD}^{2} 1^{+}\left(10^{3} / \mu \mathrm{L}\right)$ & $2,30 \pm 0,27^{\mathrm{a}}$ & $2,47 \pm 0,82^{\mathrm{a}}$ & $10,31 \pm 4,77^{\mathrm{b}}$ \\
\hline $\mathrm{CD3}^{+}\left(10^{3} / \mu \mathrm{L}\right)$ & $2,92 \pm 2,26$ & $2,62 \pm 0,44$ & $3,68 \pm 1,58$ \\
\hline $\mathrm{CD3}^{+} \mathrm{CD4}^{+}\left(10^{3} / \mu \mathrm{L}\right)$ & $0,95 \pm 0,28$ & $0,91 \pm 0,32$ & $0,87 \pm 0,14$ \\
\hline $\mathrm{CD3}^{+} \mathrm{CD8}^{+}\left(10^{3} / \mu \mathrm{L}\right)$ & $0,99 \pm 0,36$ & $1,17 \pm 0,31$ & $1,65 \pm 1,10$ \\
\hline $\operatorname{CD5}^{+} \operatorname{CD} 11 b^{+}\left(10^{3} / \mu \mathrm{L}\right)$ & $2,51 \pm 1,06^{\mathrm{a}}$ & $2,75 \pm 0,51^{\mathrm{a}}$ & $8,95 \pm 3,67^{b^{*}}$ \\
\hline
\end{tabular}

Values are mean \pm standard deviation

Different letters between columns indicated $\mathrm{P} \leq 0.05$. ${ }^{*} \mathrm{P} \leq 0.01$.

$\mathrm{CD}^{+} / \mathrm{CD}^{+}$: $\mathrm{T} \mathrm{CD}^{+} / \mathrm{T} \mathrm{CD}^{+}$lymphocytes ratio

Source: Elaborations of the authors.

Table 4. Percentage of lymphocyte subsets in the peripheral blood mononuclear cells of BLV-free (BLV) and BLVinfected cattle $\left(\mathrm{BLV}^{+}\right)$without $(\mathrm{AL})$ and with persistent lymphocytosis $\left(\mathrm{PL}^{+}\right)$performed by flow cytometry.

\begin{tabular}{lccc}
\hline \multicolumn{1}{c}{ Lymphocytes } & BLV $^{-}$ & $\mathbf{B L V}^{+} / \mathbf{A L}$ & $\mathbf{B L V}^{+} / \mathbf{P L}^{+}$ \\
\hline $\mathbf{C D 2 1}^{+}$ & $31.68 \pm 6.09^{\mathrm{a}^{* *}}$ & $42.02 \pm 10.84^{\mathrm{a}}$ & $59.18 \pm 6.96^{\mathrm{b}}$ \\
$\mathbf{C D 3}^{+}$ & $35.57 \pm 5.08^{\mathrm{a}^{* *}}$ & $25.62 \pm 2.01^{\mathrm{b}(*)}$ & $16.67 \pm 4.71^{\mathrm{c}}$ \\
$\mathbf{C D 3}^{+} \mathbf{C D 4}^{+}$ & $12.79 \pm 1.74^{\mathrm{a}^{* *}}$ & $9.89 \pm 1.54^{\mathrm{a}}$ & $5.75 \pm 2.677^{\mathrm{b}}$ \\
$\mathbf{C D 3}^{+} \mathbf{C D 8}^{+}$ & $9.65 \pm 2.50^{\mathrm{a}^{*}}$ & $7.97 \pm 1.46^{\mathrm{a}}$ & $4.31 \pm 1.19^{\mathrm{b}}$ \\
$\mathbf{C D 4}^{+} / \mathbf{C D 8}^{+}$ & $1.43 \pm 0.50$ & $1.28 \pm 0.36$ & $1.21 \pm 0.45$ \\
\hline
\end{tabular}

Values are mean \pm standard deviation

Different letters between columns indicated $\mathrm{P} \leq 0.05 .{ }^{*} \mathrm{P} \leq 0.01 .{ }^{(*)} \mathrm{P} \leq 0.01$ between $\mathrm{BLV} V^{*}$ and $\mathrm{BLV}^{+} / \mathrm{PL}^{-}$animals. ${ }^{* *} \mathrm{P} \leq 0.001$.

$\mathrm{CD}^{+} / \mathrm{CD}^{+}: \mathrm{T} \mathrm{CD}^{+} / \mathrm{T} \mathrm{CD} 8^{+}$cells ratio

Source: Elaborations of the authors. 
The increase in the number of circulating $\mathrm{B}$ lymphocytes were correlated with an augment in the number of $\mathrm{T}$ lymphocytes $(\mathrm{r}=0.90 ; \mathrm{P}=0.038)$ and $\mathrm{T} \mathrm{CD}^{+}$cells $(\mathrm{r}=0.96 ; \mathrm{P}=0.011)$, however the same cannot be applied for $\mathrm{T} \mathrm{CD}^{+}$cells $(\mathrm{r}$ $=-0.32 ; \mathrm{P}=0.60)$ in $\mathrm{BLV}$-infected dairy cows with PL. Otherwise, the number of circulating B lymphocytes were not correlated with the number of T lymphocytes $(\mathrm{r}=0.10 ; \mathrm{P}=0.95), \mathrm{T} C D 8^{+}$cells $(\mathrm{r}=$ $0.67 ; \mathrm{P}=0.22)$ and $\mathrm{T} \mathrm{CD} 4^{+}$lymphocytes $(\mathrm{r}=-0.40$; $\mathrm{P}=0.50)$ in AL animals. Besides that, the number of B lymphocytes were not correlated with the number of $\mathrm{T}$ lymphocytes $(\mathrm{r}=0.56 ; \mathrm{P}=0.32), \mathrm{T} \mathrm{CD} 8^{+}$cells $(\mathrm{r}=0.68 ; \mathrm{P}=0.21)$ and $\mathrm{T} \mathrm{CD}^{+}$lymphocytes $(\mathrm{r}=$ $0.61 ; \mathrm{P}=0.28)$ in negative-control animals.

\section{Discussion}

BLV tropism for B cells has been well documented and these cells harbor the highest proviral load (SCHWARTZ et al., 1994). Thus, it is known that animals infected with BLV showing PL present an increase in the percentage of $B$ lymphocytes (GILLET et al., 2007), as encountered here. In addition, the markers of infected cells frequently increase as CD5 and CD11b molecules. The BLV tropism for B cells and the modulation of the apoptosis in infected cells (FLORINS et al., 2007, GILLET et al., 2007, SOUZA et al., 2011) can explain the significant augment in $\mathrm{CD} 21^{+}, \mathrm{CD}^{+}$ and $\mathrm{CD}_{11 \mathrm{~b}^{+} \text {cells found here. }}$

As a result of the significant augment of B cells, a corresponding decrease in the percentage of others cells types as T cells can be observed. Nevertheless, the absolute numbers of $\mathrm{T}$ cells subsets were not altered in the present study. Similarly, Taylor et al. (1992) described no significant perturbation in the absolute numbers of circulating $\mathrm{T}$ lymphocytes subsets in BLV infected cattle with PL. Conversely, some authors point out to an increase in the absolute numbers of $\mathrm{T}$ cells in BLV-infected cattle with and without PL (WILLIAMS; AMBRORSKI; DAVIS, 1988). On the other hand, others indicate a decrease in the absolute numbers of T cells, $\mathrm{T} \mathrm{CD}^{+}$ lymphocytes and $\mathrm{T} \mathrm{CD}^{+}$cells in BLV-infected cattle with PL (GATEI et al., 1989). Wu et al. (1999) demonstrated a reduction in the percentage of $\mathrm{CD}^{+}, \mathrm{CD}^{+}$and $\mathrm{CD}^{+}$cells in the peripheral blood, as encountered here, and an increase of these populations in the spleen in BLV-infected animals with lymphoma.

It should be emphasized that the criteria of classification of an infected animal here differs from the others studies that only used the AGID test. Indeed, the animals in the present study were classified as PL upon 95\% prediction limit of lymphocyte counts for non-infected cattle (THURMOND et al., 1990, BRENNER; AVIDAR; LAHAV, 2007). Thus, animals considered to be AL in the present study might have been regarded as PL in some of the previous studies (WILLIAMS; AMBRORSKI; DAVIS, 1988, GATEI et al., 1989) based upon criteria established in 1968 by the International Committee on Bovine Leukosis (1968).

Taylor et al. (1992) reported a significant correlation between the number of circulating $B$ lymphocytes and $\mathrm{T}$ cells subpopulations ( $\mathrm{T}$ cells, $\mathrm{T} \mathrm{CD}^{+}$lymphocytes and $\mathrm{T} \mathrm{CD} 8^{+}$lymphocytes) in BLV-infected cows with PL. These authors suggest that the chronically interaction between $\mathrm{B}$ infected cells and $\mathrm{T}$ CD4 ${ }^{+}$cells (presenting antigen cells) would result in activation of $\mathrm{T} \mathrm{CD}^{+}$lymphocytes with subsequent expansion of all major lymphocytes subpopulations. Nevertheless, the present study does not strength this idea. With this in mind, the infected cells which express the viral antigens are rapidly eliminated by the cytotoxic and humoral responses, however these response are unable to destroy cells in which viral transcription is completely silenced. Thus, the inhibition of the apoptosis of BLV-infected cells and the lack of viral antigens expression in infected cells are crucial to the development of PL. Indeed, there is no evidence that the cell expansion is responsible to the augment of circulating lymphocytes in BLV-infected cows 
with PL (FLORINS et al., 2007; GILLET et al., 2007).

The present study found a significant and positive strong correlation between $\mathrm{B}$ cells and $\mathrm{T}$ cells or $\mathrm{T} \mathrm{CD} 8^{+}$lymphocytes in BLV-infected cows with PL, but the same cannot be predicted between $\mathrm{B}-$ and $\mathrm{T} \mathrm{CD} 4^{+}$lymphocytes in these animals. No such correlations were found in AL and negativecontrol animals. In fact, BLV can infect $\mathrm{T} \mathrm{CD} 8^{+}$ cells (SCHWARTZ et al., 1994) and inhibits the apoptosis in infected cells (FLORINS et al., 2007, SOUZA et al., 2011), whereas T CD4+ lymphocytes did not bear the provirus (SCHWARTZ et al., 1994). Altogether, we hypothesize that the significant correlation between the number of $\mathrm{B}$ cells and $\mathrm{T}$ $\mathrm{CD}^{+}$cells may indicate the contribution of $\mathrm{T} \mathrm{CD} 8^{+}$ lymphocytes in augment of circulating lymphocytes in BLV-infected cows with PL. Although, the proviral load was much higher in B cells compared to $\mathrm{T} \mathrm{CD} 8^{+}$lymphocytes. Indeed, in BLV investigations using sheep, proviral integration and an increase in circulating $\mathrm{T} \mathrm{CD}^{+}$cells precede seroconversion and the development of PL (WARD; DIMMOCK; EAVES, 1992).

\section{Acknowledgements}

This study was supported by São Paulo State Foundation Research (FAPESP) (project 07/560698).

\section{References}

BRENNER, J.; AVIDAR, J.; LAHAV, D. Bovine leukemia virus infection should also be considered in the differential diagnosis of nonspecific clinical manifestations. Israel Journal of Veterinary Medicine, Tel Aviv, v. 62, n. 1, p. 30-31, 2007.

DIVERS, T. J.; PEEK, S. F. Rebhunn's diseases of dairy cattle. St. Louis: Saunders Elsevier, 2008. 704 p.

FLORINS, A.; GILLET, N.; ASQUITH, B.; BOXUS, M.; BURTHEAU, C.; TWIZERE, J-C.; URBAIN, P.; VANDERMEERS, F.; DEBACQ, C.; SANCHEZ-
ALCARAZ, M. T.; SCHWARTZ-CORNIL, I.; KERKHOFS, P.; JEAN, G.; THEWIS, A.; HAY, J.; MORTHEUX, F.; WATTEL, E.; REICHERT, M.; BURNY, A.; KETTMANN, R.; BANGHAM, C.; WILLEMS, L. Cell dynamics and immune response to BLV infection: an unifying model. Frontiers in Bioscience, Irvine, v. 12, p. 1520-1531, 2007.

GATEI, M. H.; BRANDON, R. B.; NAIF, H. M.; MCLENNAN, M. W.; DANIEL, R. C. W.; LAVIN, M. F. Changes in B cell and T cell subsets in bovine leukaemia virus-infected cattle. Veterinary Immunology and Immunopathology, Amsterdam, v. 23, n. 1-2, p. 139147, 1989.

GILLET, N.; FLORINS, A.; BOXUS, M.; BURTHEAU, C.; NIGRO, A.; VANDERMEERS, F.; BALON, H.; BOUZAR, A-B.; DEFOICHE, J.; BURNY, A.; REICHERT, M.; KETTMMAN, R.; WILLEMS, L. Mechanisms of leukemogenesis induced by bovine leukemia virus prospects for a novel anti-retroviral therapies in human. Retrovirology, London, v. 4, n. 18, p. 1- 32, 2007.

INTERNATIONAL Committee on Bovine Leukosis. Criteria for the determination of the normal and leukemic state in cattle. Journal of the National Cancer Institute, Oxford, v. 41, p. 243-263, 1968.

NGUYEN, V. K.; MAES, R. F. Evaluation of an enzymelinked immunosorbent assay for detection of antibodies to bovine leukemia virus in serum and milk. Journal of Clinical Microbiology, Washington, v. 31, n. 4, p. 979981, 1993.

SCHWARTZ, I.; BENSAID, A.; POLACK, B.; PERRIN, B.; BERTHELEMY, M.; LEVY, D. In vitro leukocyte tropism of bovine leukemia virus in sheep and cattle. Journal of Virology, Washington, v. 68, n. 7, p. 45894596, 1994.

SOUZA, F. N.; LATORRE, A. O.; CANICEIRO, B. D.; SAKAI, M.; KIELING, K.; BLAGITZ, M. G.; DELLA LIBERA, A. M. M. P. Proliferação de linfócitos e apoptose de células $\mathrm{CD}^{+}$de bovinos naturalmente infectados pelo vírus da leucose enzoótica bovina. Arquivo Brasileiro de Medicina Veterinária e Zootecnia, Belo Horizonte, v. 63, n. 5, p. 1124-1130, 2011.

TAYLOR, B. C.; STOTT, J. L.; THURMOND, M. A.; PICANSO, J. P. Alteration in lymphocyte subpopulations in bovine leukosis virus-infected cattle. Veterinary Immunology and Immunopathlogy, Amsterdam, v. 31, n. 1-2, p. 35-47, 1992. 
THURMOND, M. C.; CARTER, R. L.; PICANSO, J. P.; STRALKA, K. Upper-normal prediction limits of lymphocyte counts for cattle not infected with bovine leukemia virus. American Journal of Veterinary Research, Washington, v. 51, n. 3, p. 466-470, 1990.

WARD, W. H.; DIMMOCK, C. K.; EAVES, F. W. T lymphocytes response of sheep to bovine leukaemia virus infection. Immunology and Cell Biology, Sidney, v. 70, p. 329-336, 1992.
WILLIAMS, D. L.; AMBRORSKI, G. F.; DAVIS, W. C. Enumeration of T and B cells lymphocytes in bovine leukemia virus-infected cattle, using monoclonal antibodies. American Journal of Veterinary Research, Washington, v. 49, n. 7, p. 1098-1103, 1988.

WU, D.; TAKAHASHI, K.; LIU, N.; KOGUCHI, A.; MAKARA, M.; SASAKI, J.; GORYO, M.; OKADA, K. Distribution of T-lymphocyte subpopulation in blood and spleen of normal cattle and cattle with enzootic bovine leukosis. Journal of Comparative Pathology, Amsterdam, v. 120, n. 2, p. 117-127, 1999. 